\title{
FRESHWATER DECAPODA TRACE FOSSILS IN FLOODPLAIN PALEOSOLS OF MARILIA FORMATION IN MINAS GERAIS STATE (SE BRAZIL)
}

\author{
DIEGO LUCIANO DO NASCIMENTO, ALESSANDRO BATEZELLI \\ \& FRANCISCO SÉRGIO BERNARDES LADEIRA \\ Source to sink and Paleopedology Research Group (SPRG), Instituto de Geociências, UNICAMP, \\ Campinas, SP, Brazil.dih.sapo@gmail.com,abatezelli@ige.unicamp.br, fsbladeira@ige.unicamp.br
}

\begin{abstract}
The Marilia Formation (Bauru Group, Bauru Basin) is an important record of the Upper Cretaceous in Brazil, and hosts an important fossil content. However, works regarding continental ichnology in this unit are still scarce. In order to improve this knowledge, the present work describes the occurrence of Camborygma litonomos in paleosols developed from floodplain deposits of the Marilia Formation in the Minas Gerais State. This trace fossil is associated with the activity of freshwater crayfishes, digging the soil looking for protection and to avoid the carapace dryness. Crayfish body fossils have not yet been described in deposits of the Bauru Group, thus, the trace fossil here recorded is the exclusive evidence of this organism, which is of great importance to the knowledge of the invertebrates paleodiversity of the Marilia Formation during the Late Cretaceous.
\end{abstract}

Key words: ichnology, Camborygma litonomos, crustaceans, Upper Cretaceous, Bauru Group, paleopedology.

RESUMO - A Formação Marília (Grupo Bauru, Bacia Bauru) é um importante registro do Cretáceo Superior no Brasil e possui um importante conteúdo fossilífero. No entanto, os trabalhos sobre icnologia continental desta unidade ainda são escassos. A fim de ampliar este conhecimento, o presente trabalho descreve a ocorrência de Camborygma litonomos em paleossolos desenvolvidos em depósitos de planície de inundação no Estado de Minas Gerais. Estes icnofósseis estão associados à atividade de lagostins de água doce que escavam o solo em busca de proteção e para evitar o ressecamento da carapaça. Até o momento, não foram descritos fósseis destes artrópodes no Grupo Bauru. Assim, o icnofóssil aqui registrado é a evidência exclusiva deste organismo, que é de grande importância para o conhecimento da paleodiversidade de invertebrados da Formação Marília durante o Neocretáceo.

Palavras-chave: icnologia, Camborygma litonomos, crustáceos, Neocretáceo, Grupo Bauru, paleopedologia.

\section{INTRODUCTION}

The Marilia Formation is a sedimentary succession located in the Bauru Basin, an intraplate basin of southeastern Brazil, which records the Upper Cretaceous series. The paleoenvironmental interpretations of this unit were mainly based in their abundant fossil record, which has been the subject of many studies in recent decades, especially based on dinosaurs, crocodiles, fishes, mollusks, and turtles (Bertini et al., 1993; Candeiro et al., 2006, 2008; Carvalho et al., 2007; Marinho et al., 2013; Marsola et al., 2016). However, the studies are still scarce in the case of trace fossils, with just some works referred to the Bauru Basin (Fernandes \& Carvalho, 2006; Carvalho et al., 2009; Cardoso et al., 2013; Nascimento et al., 2017a; Mineiro et al., 2017).

Trace fossils are biogenic structures produced by the activity of an organism in the substrate (bioturbation structures, bioerosion and biodeposition), reflecting the behavioral functions (ethology) related to the morphology of the organism that produces it (Bromley, 1990). Furthermore, as the structures are produced in situ, trace fossils are an important paleoenvironmental proxy (Hasiotis, 2007).

Soils are the products of major evolutionary events in the history of life on earth and record changes in terrestrial ecosystems (Retallack, 2001). One of the tools for understanding the dynamics of terrestrial ecosystems over geological time is the study of the trace fossils associated with the activity of invertebrates in paleosols.

Therefore, the characterization of trace fossils in the paleosols of the Marilia Formation can increase the knowledge about the fauna and the paleoecological conditions of this unit. There is little information concerning the invertebrate fauna of the Marilia Formation, most of the works documenting the occurrence of mollusks (Mezzalira, 1974; Mezzalira \& De Simone, 1999; Dias-Brito et al., 2001).

The trace fossils preserved in paleosols are often the only available evidence to study the diversity of organisms with low potential of preservation, such soil-dwelling organisms (Hasiotis, 2007; Genise, 2017). In order to fill part of this gap, the objective of this work is to record the occurrence of Camborygma isp. in the paleosols of the Marilia Formation and its contribution to the paleoenvironmental and paleoecological interpretations.

These trace fossils are representative of the Camborygma Ichnofacies, typical in paleosols since the Triassic (Genise et al., 2016; Genise, 2017). However, it had not yet been registered in Brazil. In this way, the present work collaborates with the knowledge about the expansion and recurrence of paleosol ichnofacies along the Cretaceous. 


\section{GEOLOGICAL SETTING}

The Bauru Basin is an Upper Cretaceous continental basin originated by flexural process during the Alto Paranaíba Uplift event in the Southeastern Brazil (Fernandes, 1998; Batezelli, 2015). It is one of the most documented sedimentary basins in Brazil, with available data including more than 500 outcrops descriptions (350 outcrops described by Fernandes, 1998 and 150 outcrops described in Batezelli, 2003).

The substrate of the basin is partly formed by the Caiuá Group sandstones (Lower Cretaceous) and the Serra Geral Formation basalts (São Bento Group, Lower Cretaceous), rearranged as an elongated NE-SW-trending depression, the sedimentation controlled by uplifts in the northern and northeastern portion. The basin records continental sedimentation (Bauru Group) with maximum thicknesses of about $300 \mathrm{~m}$, constituted by mudstones and very fine sandstones at the base (Araçatuba Formation), grading to fine- to medium-grained sandstones in the intermediate portion (Adamantina and Uberaba formations), and fine- to coarse-grained, also conglomeratic, sandstones at the top (Marilia Formation) (Figure 1).

The trace fossils described in this work occur in the paleosols of the Marilia Formation from the Upper Cretaceous (Maastrichtian) located in western Minas Gerais State (MG), southeastern Brazil (Figure 2), and were described in detail by Batezelli (2015) and Nascimento et al. (2017b). The Marilia Formation in the study area consists predominantly of sandstones and matrix-supported conglomerates, subordinated sandy-clay deposits, and $\mathrm{CaCO}_{3}$ rich paleosols (calcretes).

Based on the integration of paleontological data (Gobbo-Rodrigues, 2001; Dias-Brito et al., 2001; Santucci \& Bertini, 2001; Martinelli et al., 2011; Fragoso et al., 2013), stratigraphic information (Batezelli, 2015), as well as correlations with tectonic and magmatic events (Amaral et al., 1967; Hasui \& Cordani, 1968; Sonoki \& Garda, 1988; Machado Junior, 1992) that occurred in the northern and northeastern portions of the Bauru Basin, a Maastrichtian age is admitted for the Marília Formation.

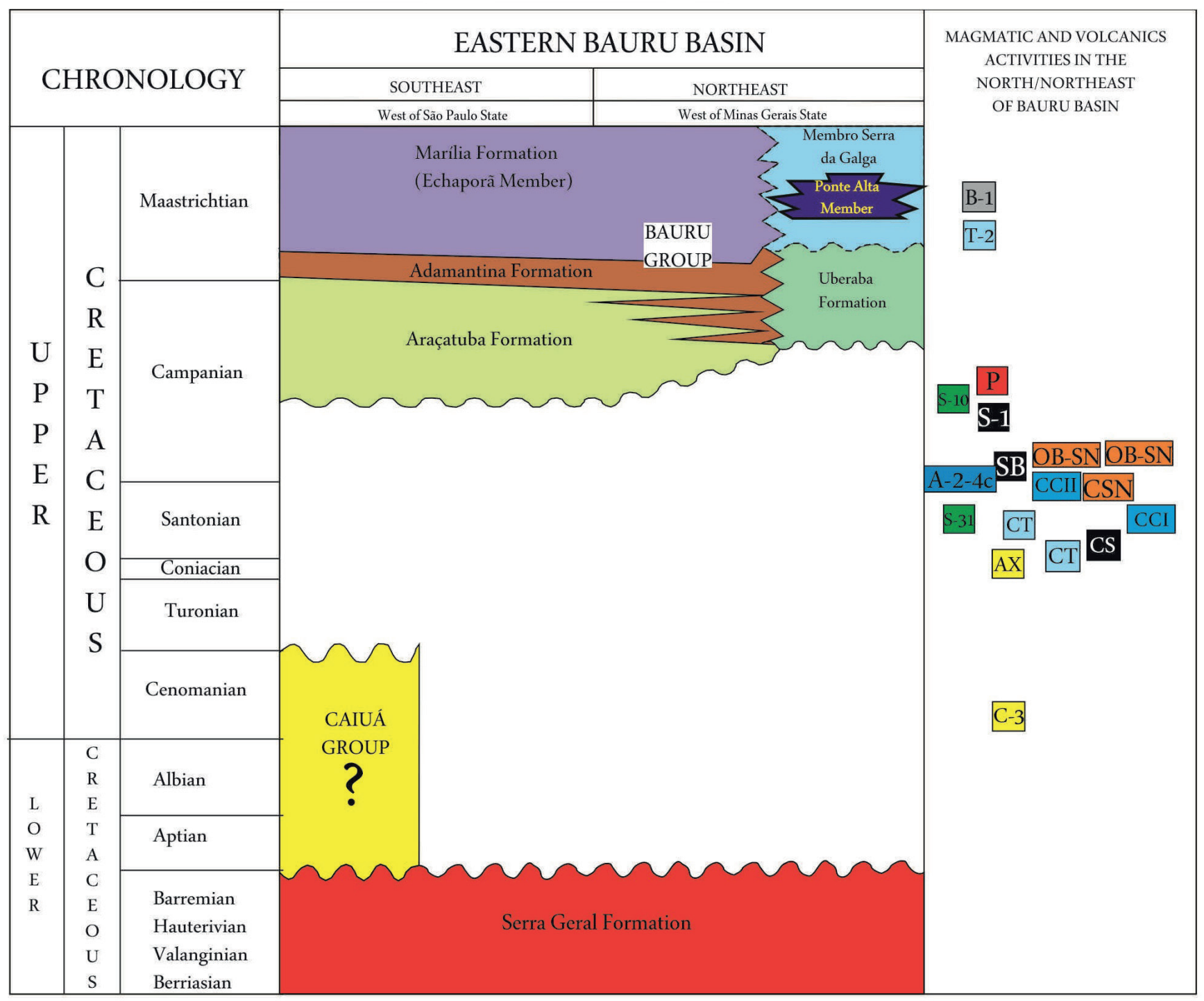

Figure 1. Chronostratigraphic chart of the Cretaceous sequence in Bauru Basin (Batezelli, 2015). 


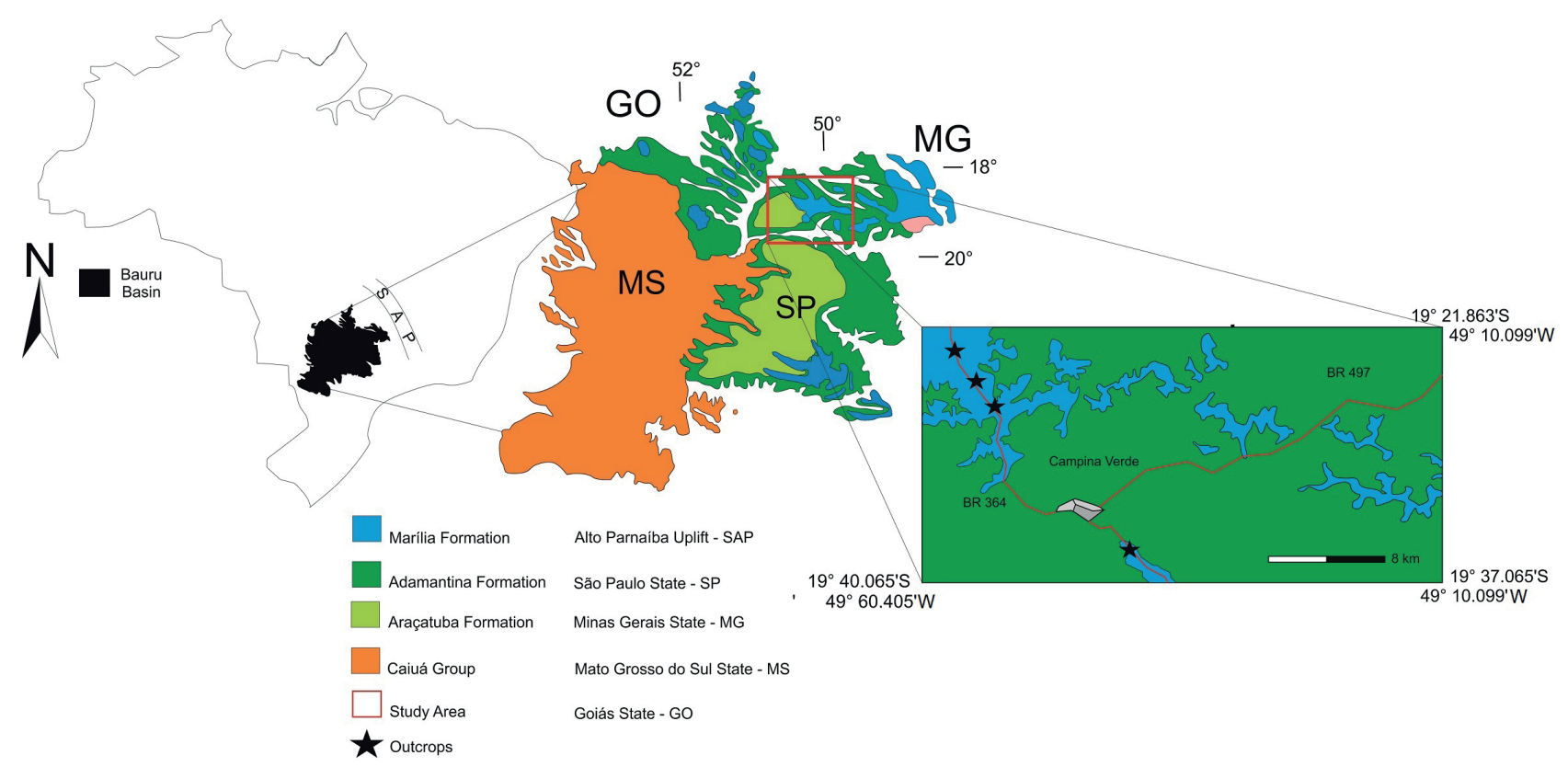

Figure 2. Map of localization of study area of the Bauru Basin.

The outcrops of the Marilia Formation are densely bioturbated and cemented, resulting in the almost total obliteration of many sedimentary structures. However, it is possible to distinguish two different facies associations: fluvial deposits, and floodplain deposits composed of sandyconglomeratic and clay deposits, respectively.

The paleosols occur interspersed with sandstones and conglomerates consisting of clasts of quartz, carbonate and bioclasts. The depositional architectures of the Marilia Formation are associated to river channels, lenticular sandbars and floodplain elements (e.g. Miall, 1996), constituting amalgamated channel complexes, interspersed with paleosols (Batezelli, 2015; Nascimento et al., 2017b).

The semi-arid climate of the Marilia Formation is attested by the large amount of calcretes that are common in environments with annual rainfall between 400 and 600 $\mathrm{mm}$ (Goudie, 1983), and by clay minerals from the group of illite and palygorskite/sepiolite (Suguio \& Barcellos, 1983; Goldberg \& Garcia, 2000), as well as paleoprecipitation proxies (Pereira et al., 2015).

\section{MATERIAL AND METHODS}

The sedimentological analysis was based on the analysis of four outcrops where the paleosols were described according to the recommendations of Miall (1996) for the facies and their associations, using photographic mosaics to identify and interpret the external architecture and geometry of the deposits. The lithostratigraphic sections range from 5 to 15 $\mathrm{m}$ in height and are located near of Campina Verde, $\mathrm{MG}$ $\left(19^{\circ} 40.065^{\prime} \mathrm{S}, 49^{\circ} 60.405^{\prime} \mathrm{W}\right)$ (Figure 2). They were studied in detail by Batezelli (2015) and Nascimento et al. (2017b).

Paleosols were described as recommended by the Soil Survey Manual (Soil Survey Staff, 1999), and Retallack (2001), who emphasizes the identification of horizons, color, presence of nodules, as well as bioturbation standards (rhizolith and burrows). The micromorphological descriptions were performed with the help of a petrographic microscope following the methodology of Stoops et al. (2010).

The ichnological description was based in Hasiotis (2002), and its characterization considered main ichnotaxobases, as proposed by Bromley (1990), such as general form, type of wall structure, type of branching, and nature of the fill. The description included the elaboration of sketches, drafts, and photographs for the documentation and the dimensional characterization of trace fossils. The morphological description sought to emphasize the distribution, size, geometry, frequency, and orientation concerning sedimentary facies, paleosols and other ichnological assemblages, as well as the superficial morphological characteristics, such as cementation and filling of the chambers.

\section{RESULTS}

The analysis of the deposits of the Marilia Formation resulted in six sedimentary facies (Table 1), which were grouped into three facies associations, related to the following depositional paleoenvironments: fluvial deposits and floodplain fines.

The parent material of paleosols of the Marilia Formation in the studied area comprises red to pinkish sand from the Lenticular Sandbars Facies Association (facies St and Sm), conglomeratic deposits from the Amalgamated Channels Facies Association (facies Gmm and Gt), and fines deposits from the Floodplain Facies Association (facies St, Fm and Fl) (Table 1). The exposition is $15 \mathrm{~m}$ high, have metric thicknesses and a lateral exposure up to $100 \mathrm{~m}$ (Figures 3A-B).

The Lenticular Sandbars Facies Association comprises poorly sorted medium to coarse sandstones with subangular grains, besides angular clasts of 0.4 to $3.0 \mathrm{~cm}$ in diameter 
Table 1. Synthesis of the general characteristics of the deposits described in study area.

\begin{tabular}{clll}
\hline Facies & Facies Associations & Architectural elements & \multicolumn{1}{c}{ Characteristics } \\
\hline St, Sm, Gmm and Gt & $\begin{array}{l}\text { Amalgamated channels, } \\
\text { lenticular sandbars }\end{array}$ & $\begin{array}{l}\mathrm{CH} \text { (channel), } \\
\mathrm{SB} \text { (sand bedform) }\end{array}$ & $\begin{array}{l}\text { Lenticular bodies of sandstones and } \\
\text { conglomerates with concave base marked by } \\
\text { intraformational conglomerate with fining } \\
\text { upward. These deposits occur eroding floodplain } \\
\text { deposits and paleosols. }\end{array}$ \\
\hline
\end{tabular}

$\begin{array}{ll}\text { Floodplain, } & \text { Fm and Fl } \\ \text { overbank fines } & \text { FF (Floodplain fines) }\end{array}$

Massive mudstones and sandstones (overbank) with oxidation features (rhizohalos), intensely bioturbated and pedogenized.
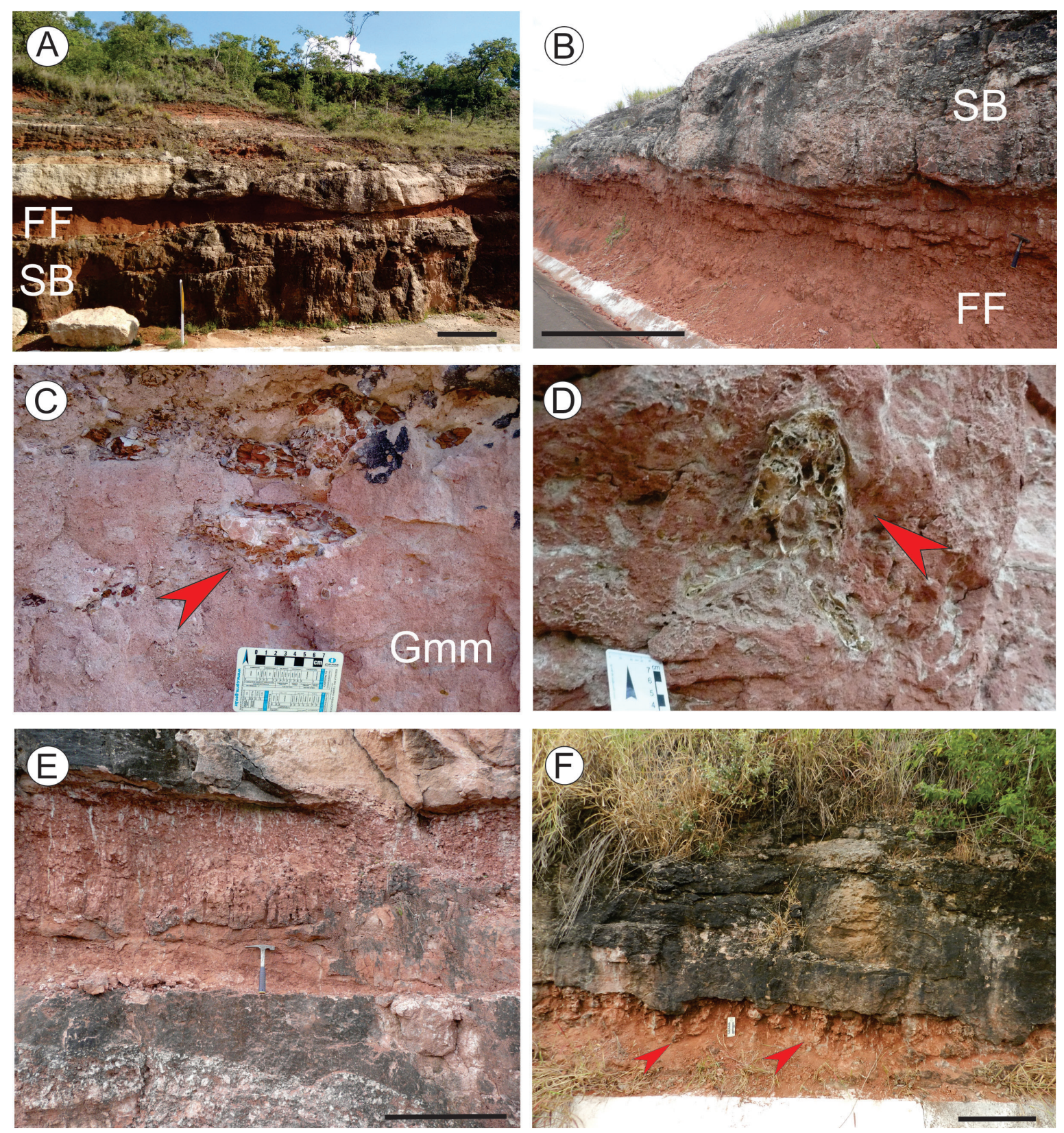

Figure 3. General aspects of some architectonic elements and facies of the Marilia Formation in the studied area. A-B, despite of pedogenetic process, the architectural elements are still visible. Note that the floodplain elements (FF) are truncated by channel deposits and sandy bars (SB). C, facies Gmm composed large mudstone clasts. D, vertebrate fossil in conglomeratic deposits (Facies Gmm). E-F, floodplain facies association eroded by channel deposits. Arrow heads in $\mathrm{F}$ indicates where Camborygma litonomos is preserved. Scale bars: $\mathrm{A}=2,5 \mathrm{~m}$; $\mathrm{B}=$ $1,2 \mathrm{~m} ; \mathrm{E}=60 \mathrm{~m} ; \mathrm{F}=30 \mathrm{~m}$. 
scattered along the profile. The conglomerates of the Amalgamated Channels Facies Association have fragments of reworked quartz, flint, calcretes, and $\mathrm{CaCO}_{3}$ nodules that range from 1 to $10 \mathrm{~cm}$ in diameter in a fining upward sequence (Figure 3C).

Sedimentary structures are present in St facies, but poorly preserved, they consist of small to medium-sized laminations and cross-beddings that are rich in carbonate nodules and bioclasts (vertebrate bones) (Figure 3D). The basal contacts (Gmm and Gt facies) of these deposits are conglomeratic and erosive, predominantly horizontal to sub-horizontal.

The Floodplain Fines Association is composed of dark red and brown claystones (facies $\mathrm{Fl}$ and $\mathrm{Fm}$ ), predominantly consisting of clay (Figures 3C-D), with variations in the sand content (facies $\mathrm{St}$ ). The $\mathrm{Fl}$ and $\mathrm{Fm}$ facies are bioturbated and pedogenized in some exposures. Laterally they occur as metric lenticular layers, representing the most distal portions of the floodplains.

The facies association composes the architectural elements, which are indicative of a fluvial environment that comprise lenticular sandbars (SB) and poorly confined, multistory, amalgamated channels $(\mathbf{C H})$ and clayey-sandy deposits (FF) associated to deposition in distal floodplains. The mudstones with redoximorphic and bioturbation associated with pedogenesis obliterates the contact surfaces between the different deposits. There is no evidence of preservation of organic matter in these deposits.

\section{Studied paleosols}

The paleosols where Camborygma occur are composed of stacked C horizons (Figure 4A) with evidence of oxidation and reduction processes, such as rhizohalos (Figure 4B). The main distinguishing feature of this pedotype is the argillaceous parent material (Figures $4 \mathrm{C}-\mathrm{D}$ ) with pinkish white $(2,5 \mathrm{YR} 8 / 2)$ and weak red $(7,5 \mathrm{R} 5 / 3)$ colors. The micromorphological analysis shows a groundmass composed of argillic and sand material; the matrix is mostly inherited from the source material (Figure 4E). The quartz grains are immersed in this fine matrix, composing a loose arrangement of the grains, which results in a relative distribution, ranging from eunalic to chitonic.

The coatings are associated with alteration of primary minerals, resulting in a crystallitic to granostriated b-fabric (Figure 4F).

\section{SYSTEMATIC ICHNOLOGY}

Camborygma (Hasiotis \& Mitchell, 1993)

Camborygma litonomos (Hasiotis \& Mitchell, 1993) (Figures 5A-F)

Description. simple, cylindrical, vertical to subvertical burrows. The burrows are lined with a thin material and filled with medium and poorly sorted sand indicating passive filling. The surface morphology of the burrow display scratch and stretch marks. The trajectory is helical or winding, with up to $50 \mathrm{~cm}$ in length and $10 \mathrm{~cm}$ in diameter. Generally, the burrows maintain the diameter throughout of their length, but may display constrictions or nodules throughout the structure, which presents sub-spherical to spherical chambers in your base.

Remarks. Due to their architecture, surficial morphology, burrows predominantly quasi-vertical, absence of branches and basal chamber, these structures are attributed to Camborygma litonomos Hasiotis \& Mitchell, 1993 (see also Hasiotis \& Honey, 2000). This trace fossil represents the activity of freshwater crayfishes (Decapoda: Cambaridae). The morphology and stratigraphic position of C. litonomos indicates that the trace maker digged the areas near to channels or flooded environments, looking for protection to be able to reproduce using their appendages to dig and manipulate sediment, as well to avoid carapace dryness in semiaquatic environments, that are exposed to subaerial conditions during part of the year (Hobs, 1981; Hasiotis \& Mitchell, 1993; Walls, 2009; Genise, 2017).

\section{Rhizohalos}

\section{RHIZOLITHS}

Characteristics of $\mathrm{Fe}$ depletion in predominantly vertical shape, yellow and grey tones, with horizontal lateral ramifications. The diameter ranges from 2 to $5 \mathrm{~mm}$ and the length ranges from 10 to $15 \mathrm{~cm}$ (see Figures 6A-B). The ramifications do not have a preferential orientation, and they are distributed close to the surface with dichotomic pattern.

\section{PALEOENVIRONMENTAL INTERPRETATION}

The characteristics of the facies association described above are compatible with a fluvial channel-influenced depositional setting. The facies described (Table 1) indicates the migration of channels belts and agradation over the floodplains, resulting in the amalgamation of lenticular sandy bars (Miall, 1996; Gibling, 2006). These features are typical of environments associated with variable or ephemeral flow regimes (Fielding et al., 2011).The contact between the deposits are always marked by an erosive surface associated with multi storey sandstones, interpreted as fluvial channels migrating to distal portions of the fluvial plain directly under floodplain deposits and paleosols (Kraus \& Wells, 1999).

In the case of the biogenic structures of the Marilia Formation, these cylindrical structures have similarities with lungfish burrows. However, such structures tend to be shorter, and do not have branches (Hembree et al., 2004). Despite the record of lungfish fossils in the Marilia Formation (Alves et al., 2013), the characteristics of the Camborygma described in the present study display knobby textures on their surface, scratch and stretch marks. These characteristics are not found in trace fossils produced by lungfishes. Due to this, the most probable trace maker for $C$. litonomos is the freshwater crayfish (Decapoda), common in fluvial plains (Hasiotis \& Mitchell, 1993). According to these authors, the method used by crayfishes to make the burrows is the same through time (Triassic to present); the organism uses 

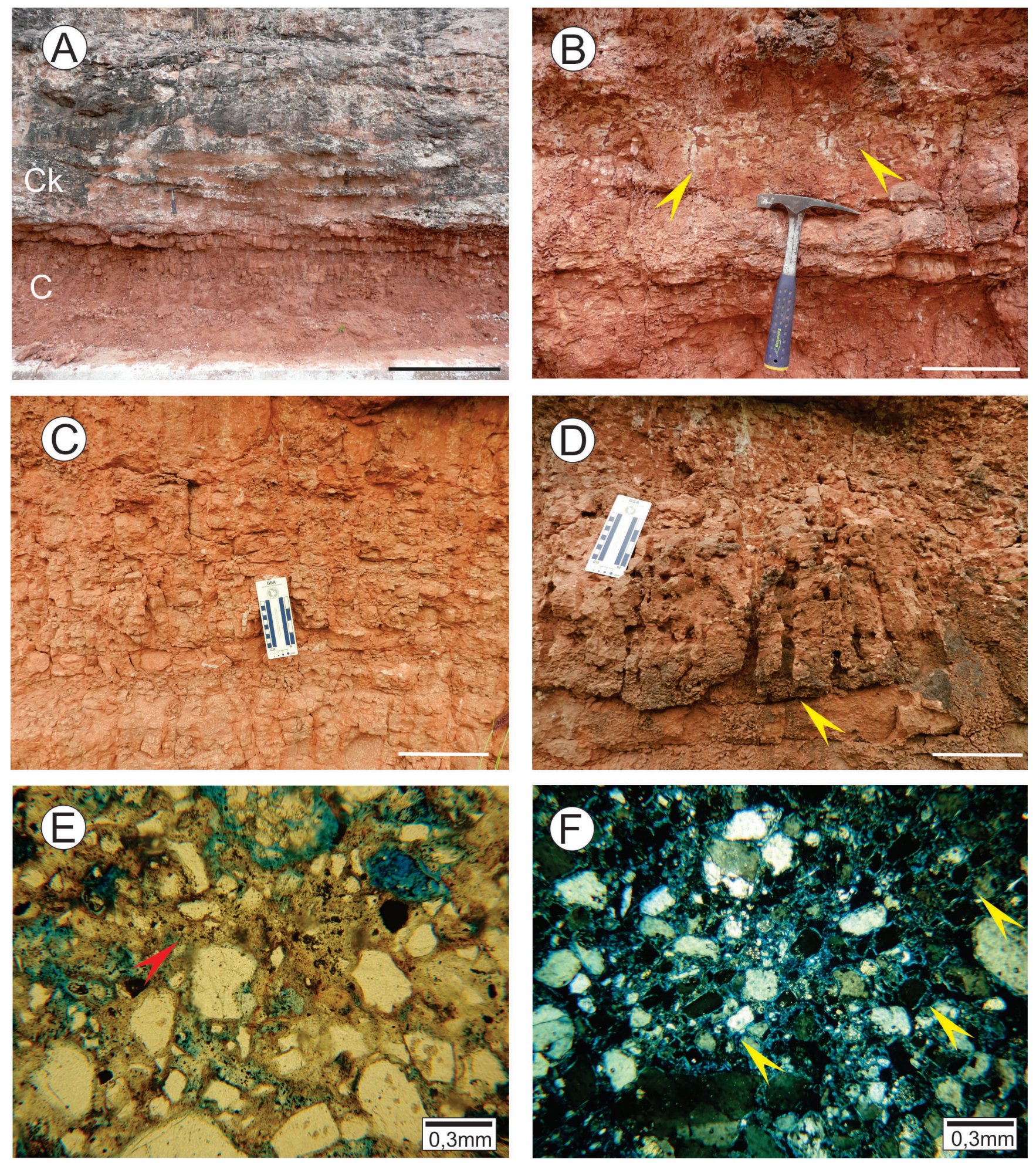

Figure 4. General aspects of floodplain paleosols. A, the $\mathbf{C}$ horizon truncated by sandbar deposits and altered by pedogenesis (Ck horizon). B, paleosols with rhizohalos; note the Fe depletion in the paleorhizosphere (arrow heads). C, massive aspect of paleosols without bioturbation. D, paleosol bioturbated by Camborygma litonomos (arrow head). E, micromorphological aspects of paleosols. The arrow indicates clayey matrix, which involves the grains. F, granostriated b-fabric of paleosols. The arrow heads indicate the orientation of the clays on the side of the grains; note that the grains also tend to be oriented. Scale bars: $A=1 \mathrm{~m} ; B-D=15 \mathrm{~cm} ; E-F=0,3 \mathrm{~mm}$. 

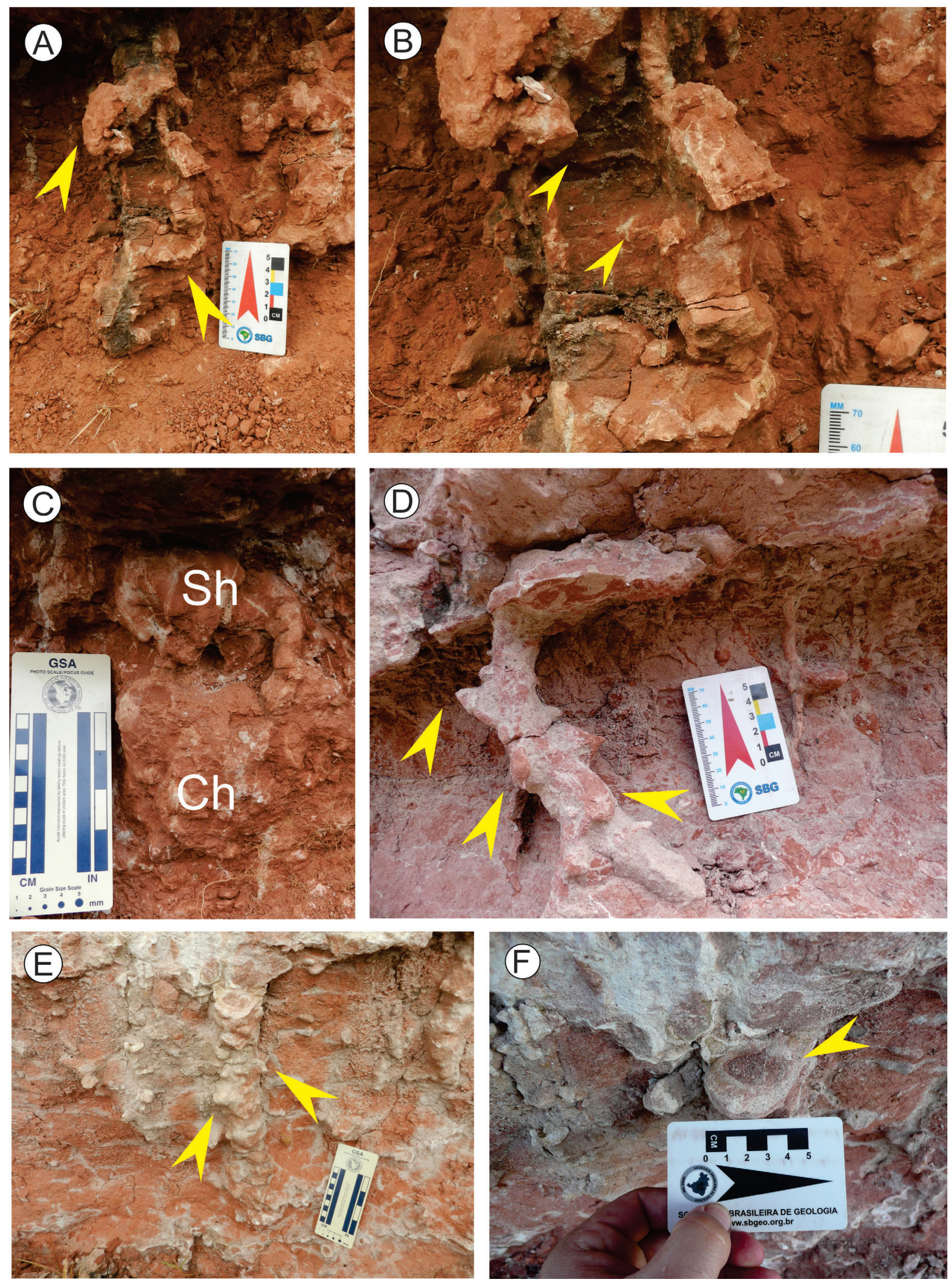

Figure 5. Examples of Camborygma litonomos. A, arrows indicate the protuberances associated with the appendages of crayfish during excavation. B, arrows indicate the scratch marks on the inside of shafts. C, picture showing the basal chamber (Ch) at the bottom (Sh, shaft). D, C. litonomos occurring associated with undetermined burrow. Arrow heads show the nodules throughout the structure. E-F, the arrow indicates the difference between the lining and infilling material. 

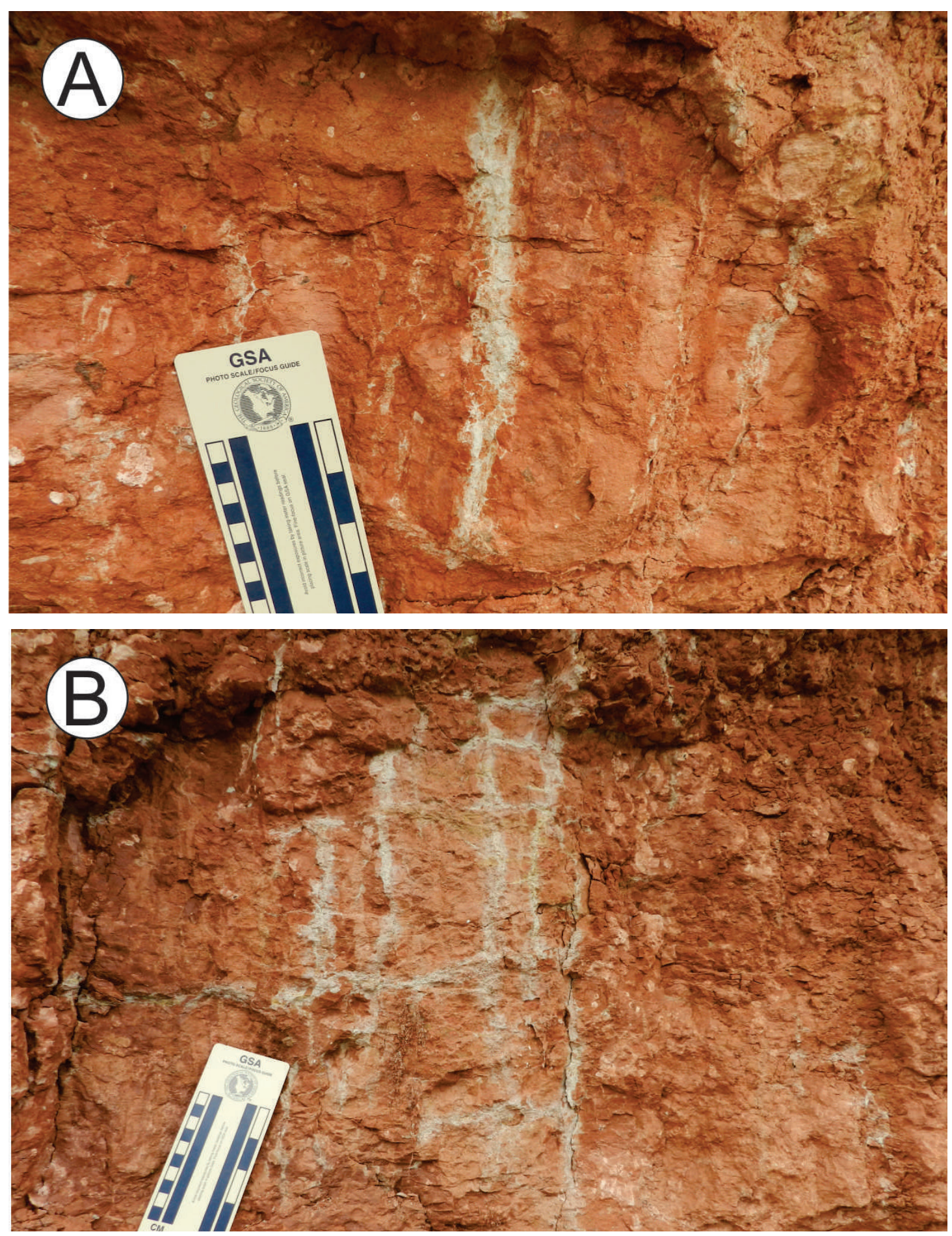

Figure 6. A-B, Rhizohalos present in studied paleosols.

its appendages for digging and manipulating sediments and soils, a well documented process for modern crayfishes (Walls, 2009). The flooded soils developed in floodplains presents the semi-aquatic environmental conditions necessary for the occurrence of crayfishes, such as oscillation of the water table and subaerially exposition (Hasiotis \& Mitchell, 1993; Hasiotis \& Honey, 2000). The morphology of their burrows is usually elongated and circular or cylindrical, with dimensions varying from a few centimeters to metric, depending on the distance from the water source (Martin, 2013; Miller et al.,
2014). Therefore, the modern freshwater crayfish burrow display the same morphology of their fossil content.

Crayfishes have hydrophilic behavior and they are dependent of freshwater sources (Buckup, 2003). Thus, the same is expected in the case of Camborygma litonomos trace maker. There are previous records of this ichnogenus in poorly drained paleosols with sandy-clay source material and high water table (Hasiotis \& Mitchell, 1993; Smith et al., 2008; Figure 7). In this way, many authors have pointed out Camborygma as structures commonly associated to paleosols 


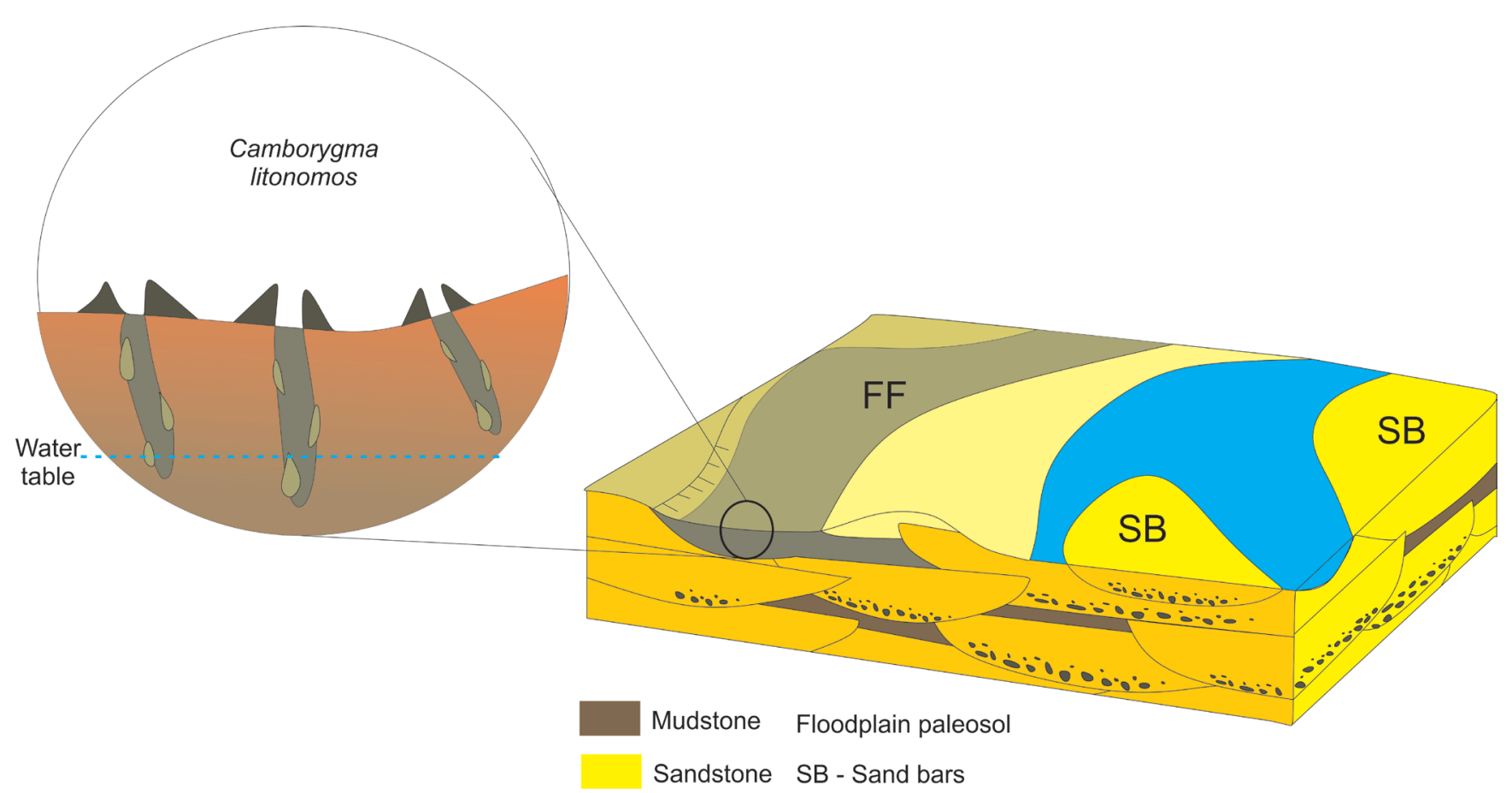

Figure 7. Paleoenviromental scenario of Marilia Formation in the study area.

developed on floodplains or wetlands settings (Betadou et al., 2009; Genise et al., 2016).

The trace fossils are reflecting a behavior in response of the drainage conditions of the substrate, as it reaches its maximum depth to intercept the water table (Smith et al., 2008). Camborygma litonomos requires a constant presence of the water table (Hasiotis \& Mitchell, 1993). In this way, this ichnotaxon indicates the oscillation of the water table in the paleotopography of the distal plains. According to the length of the burrows, the water table remained high for most of the time ranging from 40 to $50 \mathrm{~cm}$, i.e., the same length of the burrows. Modern crayfish digs the substrate looking for shelter, protection of predators and carapace dryness (Wells, 2009). This mechanism is a primitive survival behavior to intercept the water table as an exit to face the climatic seasonality, ephemerality of the fluvial channels, and the fluctuations of the water table (Walls, 2009), in this case in semi-arid conditions prevailing during the formation of the deposits of the Marilia Formation (Goldberg \& Garcia, 2000; Pereira et al., 2015).

The soil was poorly drained and regularly exposed to subaerial conditions, indicated by the presence of redoximorphic features, such rhizohalos (Kraus \& Hasiotis, 2006) and shrink-swell features, like the microfabric granostriated (Figure 3F), in response to repetitive cycles of saturation and dryness (Lindbo et al., 2010). There is no evidence of preservation of organic matter in these deposits, indicating a relatively oxidative environment associated with the sub aerial exposure of these materials, at least seasonally (Retallack, 2001).

The occurrence of rhizohalos suggest that the deposits were exposed to the advancement of pedogenesis, which allowed the colonization by plants (Kraus \& Hasiotis, 2006), probably the format of the rhizohalos was conditioned by the high water table, as indicated by their adventitious shape. This indicates relatively low sedimentation rates too, which enabled the development of soil and colonization of plains by plants (Kraus, 1999).

Camborygma is the typical representative trace fossil of the Camborygma Ichnofacies. The occurrence of this ichnofacies represents local swamps or wetlands (with a herbaceous communities) paleoenvironments (Genise et al., 2016; Genise, 2017). In addition, the ichnofacies reflects the transition period after the Permian extinction, where the continental invertebrate ichnofaunas disappear, and sequentially, these assemblages became dominated by earthworms and crayfishes, which characterize the paleoenvironmental scenario of the paleosols during the Cretaceous. Therefore the trace fossils described in Marilia, as well the trace fossil associations documented in Upper Jurassic and Lower Cretaceous paleosols in Patagonia dominated by crayfish trace fossils (Bedatou et al., 2008), are representatives of Camborygma Ichnofacies in South America.

\section{CONCLUSIONS}

The trace fossils described in this paper (Camborygma litonomos) record the activity of freshwater crayfishes, in the sedimentary successions of the Upper Cretaceous Bauru Group. C. litonomos is restricted to paleosols, which in this case were developed in the floodplain settings of a river system in a semi-arid environment.

In the Marilia Formation deposits, these burrows represent the strategy of the crayfishes to survive in an environment with 
drought periods throughout the year. The main conditioning factors to the tracemaker distribution were the presence of water, the food sources, and the paleosol clayey texture with the water table near the surface, indicated by the presence of rhizohalos and redoximorphic features. Crayfish body fossils have not yet been found in Marilia Formation. Therefore, the presence of $C$. litonomos expands the knowledge about the macroinvertebrate fauna and the continental ichnofacies associated with floodplain settings of the Marilia Formation on the Bauru Group.

\section{ACKNOWLEDGMENTS}

The authors are grateful to the São Paulo Research Foundation (FAPESP - Fundação de Amparo à Pesquisa do Estado de São Paulo) for supporting and funding Project FAPESP 2015/17632-5: "Sedimentation and pedogenesis of the Upper Cretaceous of the Bauru, Sanfranciscana, Parecis, and Neuquen basins". The third author is grateful to the CNPq for a research productivity fellowship (308629/2015-9). The authors are grateful to the editor J. Leme, and the three reviewers for their valuable comments and suggestions.

\section{REFERENCES}

Alves, Y.M.; Machado, L.P.; Bergqvist, L.P. \& Brito, P.M. 2013. Redescription of two lungfish (Sarcopterygii: Dipnoi) tooth plates from the late Cretaceous Bauru group, Brazil. Cretaceous Research, 40:243-250. doi:10.1016/j.cretres.2012.07.007

Amaral G.; Bushee J.; CordaniI U.G.; Kawashita K. \& Reynolds J.H. 1967. Potassium-argon ages of alkaline rocks from Southern Brazil. Geochimica and Cosmochimica Acta, 31:117-142.

Batezelli, A. 2010. Arcabouço tectono-estratigráfico e evolução das Bacias Caiuá e Bauru no Sudeste brasileiro. Revista Brasileira de Geociências, 40:265-285.

Batezelli, A. 2003. Análise da Sedimentação Cretácea no Triângulo Mineiro e sua Correlação com Areas Adjacentes. PhD Thesis. Geosciences and Exact Sciences Institute, São Paulo State University e UNESP, Rio Claro, São Paulo, 183 p.

Batezelli, A. 2015. Continental systems tracts of the Brazilian Cretaceous Bauru Basin and their relationship with the tectonic and climatic evolution of South America. Basin Research, 27:1-25. doi:10.1111/bre.12128

Bedatou, E.; Melchor, R.N.; Bellosi, E. \& Genise, J.F. 2008. Crayfish burrows from Late Jurassic-Late Cretaceous continental deposits of Patagonia: Argentina. Their palaeoecological, palaeoclimatic and palaeobiogeographical significance. Palaeogeography Palaeoclimatology Palaeoecology, 257:169-184. doi:10.1016/j. palaeo.2007.09.020

Bedatou, E.; Melchor, R.N.; Bellosi, E. \& Genise, J.F. 2009. Complex palaeosol ichnofabrics from Late Jurassic-Early Cretaceous volcanoclastic successions of Central Patagonia, Argentina. Sedimentary Geology, 218:74-102. doi:10.1016/j. sedgeo.2009.04.005

Bertini, R.J.; Marshall, L.G.; Gayet, M. \& Brito, P.M. 1993. The vertebrate fauna from the Adamantina and Marília formations. Upper Cretaceous of the Paraná Basin, Southeast Brazil. Neues Jahrbuch für Geologie und Paläontologie, Abhandlungen, 188:71-101.

Bromley, R.G. 1990. Trace fossils. Biology and taphonomy. London, Unwin Hyman, 280 p.
Buatois, L. \& Mángano, M.G. 2011. Ichnology organism-substrate interactions in space and time. New York, Cambridge University Press, $366 \mathrm{p}$.

Buckup, L. 2003. Familia Parastacidae. In: G.A.S. Melo (ed.) Manual de identificação dos Crustacea Decapoda de água doce do Brasil, Loyola, p. 317-398.

Candeiro, C.R.A.; Martinelli, A.G.; Ávila, L.S. \& Rich, T.H. 2006. Tetrapods from the Upper Cretaceous (Turonian-Maastrichtian) Bauru Group of Brazil: a reappraisal. Cretaceous Research, 27:923-946. doi:10.1016/j.cretres.2006.05.002

Candeiro, C.R.A.; Santos, A.R.; Bergqvist, L.P.; Ribeiro, L.C.B. \& Apesteguía, S. 2008. The Late Cretaceous fauna and flora of the Uberaba area (Minas Gerais State, Brazil). Journal of South American Earth Sciences, 25:203-216. doi:10.1016/j. jsames.2007.06.005

Cardoso, C.D.; Carvalho, I.S. \& Fernandes, A.C.S. 2013. O conteúdo icnológico da Formação Adamantina (Cretáceo superior, Bacia Bauru). In: CONGRESSO BRASILEIRO DE PALEONTOLOGIA, 23, 2013. Boletim de Resumos, Gramado, SBP, p. 300-301.

Carvalho, I.S.; Gracioso, D.E. \& Fernandes, A.C.S. 2009. Uma câmara de coleóptero (Coprinisphaera) do Cretáceo Superior, Bacia Bauru. Revista Brasileira de Geociências, 39:679-684.

Carvalho, I.S.; Vasconcellos, F.M. \& Tavares, S.A.S. 2007. Montealtosuchus arrudacamposi, a new peirosaurid crocodile (Mesoeucrocodylia) from the Late Cretaceous Adamantina Formation of Brazil. Zootaxa, 1607:35-46.

Dias-Brito, D.; Musacchio, E.A.; Castro, J.C.; Maranhão, M.S.A.S.; Suárez, J.M. \& Rodrigues, R. 2001. The Bauru group: a continental Cretaceous unit in Brazil - Concepts based on micropaleontological, oxygen isotope and stratigraphical data. Revue de Paleobiologie, 20:245-304.

Fernandes, A.C.S. \& Carvalho, I.S. 2006. Invertebrate ichnofossils from the Adamantina Formation (Bauru Basin, Late Cretaceous), Brazil. Revista Brasileira de Paleontologia, 9:211-220.

Fernandes, L.A. 1998. Estratigrafia e Evolução Geológica da Parte Oriental da Bacia Bauru (Ks, Brasil). Programa de PósGraduação em Geologia Sedimentar, Instituto de Geociências, Universidade de São Paulo, Tese de Doutorado, 216 p.

Fielding, C.R.; Allen, J.P.; Alexander, J.; Gibling, M.R.; Rygel, M.C. \& Calder, J.H. 2011. Fluvial systems and their deposits in hot, seasonal semi-arid and sub-humid settings: modern and ancient examples. In: S.K. Davidson; S. Leleu \& C.P. North (eds.) From river to rock record: the preservation of fluvial sediments and their subsequent interpretation, Boulder, Society for Sedimentary Geology, p. 89-111 (Special Publication 97). doi:10.2110/sepmsp.097.089

Fragoso, C.E.; Weinschütz, L.C.; Vega, C.S.; Guimarães, G.B.; Manzig, P.C.\& Kellner,A.W.A. 2013. Short note on the pterosaurs from the Caiuá Group (Upper Cretaceous, Bauru Basin), Paraná State, Brazil. In: INTERNATIONAL SYMPOSIUM ON PTEROSAURS, 1, 2013. Short Communications, Rio de Janeiro, p. 71-72.

Genise, J.F. 2017. Ichnoentomology: insect traces in soils and paleosols. Switzerland, Springer International Publishing, 695 p. (Topics in Geobiology 37). doi:10.1007/978-3-319-28210-7

Genise, J.F.; Bedatou, E.; Bellosi, E.S.; Sarzetti, L.C.; Sánchez, M.V. \& Krause, J.M. 2016. The Phanerozoic four revolutions and evolution of paleosol ichnofacies. In: M.G. Mángano \& L. Buatois (eds.) The trace-fossil record of major evolutionary events, Dordrecht, Springer, p. 301-370 (Topics in Geobiology 40). doi:10.1007/978-94-017-9597-5_6 
Gibiling, M.R. 2006. Width and thickness of fluvial channel bodies and valley fills in the geological record: a literature compilation. Journal of Sedimentary Research, 76:731-770. doi:10.2110/ jsr.2006.060

Gobbo-Rodrigues, S.R. 2001. Carófitas e ostracodes do Grupo Bauru. Instituto de Geociências e Ciências Exatas, Universidade Estadual Paulista, Dissertação de Mestrado, 137 p.

Goldberg, K.K. \& Garcia, A.J.V. 2000. Paleobiogeography of the Bauru Group, a dinossaur-bearing Cretaceous unit, northeastern Paraná Basin, Brazil. Cretaceous Research, 21:241-254. doi:10.1006/cres.2000.0207

Goudie, A.S. 1983. Calcrete. In: A.S. Goudie \& K. Pye (eds.) Chemical sediments and geomorphology, Academic Press, p. 93-131.

Hasiotis, S.T. 2002. Continental trace fossils. Tulsa, Society for Sedimentary Geology, 132 p. (SEPM Short Course Notes 51). doi: $10.2110 /$ scn.06.51

Hasiotis, S.T. 2007. Continental ichnology: fundamental processes and controls on trace fossil distribution. In: W. Miller (ed.) Trace fossils: concepts, problems, prospects, Elsevier, p. 268-284. doi:10.1016/B978-044452949-7/50142-X

Hasiotis, S.T. \& Honey, J.G. 2000. Paleohydrologic and stratigraphical significance of crayfish burrows in continental deposits: examples from several Paleocene Laramide basins in the Rocky Mountains. Journal of Sedimentary Research, 70:127-139. doi:10.1306/2DC40904-0E47-11D7-8643000102C1865D

Hasiotis, S.T. \& Mitchell, C.E. 1993. A comparison of crayfish burrow morphologies: Triassic and Holocene fossil, paleo- and neoichnological evidence, and the identification of their burrowing signatures. Ichnos, 2:291-314. doi:10.1080/10420949309380104

Hasui, Y. \& Cordani, U.G. 1968. Idades potássio-argônio de rochas eruptivas mesozóicas do oeste mineiro e sul de Goiás. In: BRAZILIAN GEOLOGY CONGRESS, 2, 1986. Bulletim, Belo Horizonte, p. 139-143.

Hembree, D.I.; Martin, L.D. \& Hasiotis, S.T. 2004. Amphibian burrows and ephemeral ponds of the Lower Permian Speiser Shale, Kansas: evidence for seasonality in the mid-continent. Palaeogeography, Palaeoclimatology, Palaeoecology, 203:127152. doi:10.1016/S0031-0182(03)00664-3

Hobbs, H.H. 1981. The crayfishes of Georgia. Smithsonian Contributions to Zoology, 318:1-549.

Kraus, M.J. 1999. Paleosols in clastic sedimentary rocks: their geologic applications. Earth-Science Reviews, 47:41-70. doi:10.1016/S0012-8252(99)00026-4

Kraus, M.J. \& Hasiotis, S.T. 2006. Significance of different modes of rhizolith preservation to interpreting paleoenvironmental and paleohydrologic settings: examples from Paleogene paleosols, Bighorn Basin, Wyoming, U.S.A. Journal of Sedimentary Research, 76:633-646. doi:10.2110/jsr.2006.052

Kraus, M.J. \& Wells, T.M. 1999. Recognizing avulsion deposits in the ancient stratigraphical record. In: N.D. Smith \& J. Rogers (eds.) Fluvial Sedimentology VI, Gent, International Association of Sedimentologists, p. 251-268 (Special Publication 28). doi:10.1002/9781444304213.ch19

Lindbo, D.L.; Stolt, M.H. \& Vepraskas, M.J. 2010. Redoximorphic features. In: G. Stoops; V. Marcelino \& F. Mees (eds.) Interpretation of micromorphological features of soils and regoliths, Elsevier, p. 129-147. doi:10.1016/B978-0-444-531568.00008-8

Machado Junior, D.L. 1992. Idades Rb/Sr do complexo alcalinocarbonatítico de Catalão II (GO). In: BRAZILIAN GEOLOGY CONGRESS, 29, 1992. Bulletin, São Paulo, p. 91-93.

Marinho, T.S.; Iori, F.V.; Carvalho, I.S. \& Vasconcellos, F.M. 2013. Gondwanasuchus scabrosus gen. et sp. nov., a new terrestrial predatory crocodyliform (Mesoeucrocodylia: Baurusuchidae) from the Late Cretaceous Bauru Basin of Brazil. Cretaceous Research, 44:104-111. doi:10.1016/j.cretres.2013.03.010

Marsola, J.C.; Batezelli, A.; Montefeltro, F.C.; Grellet-Tinner, G. \& Langer, M.C. 2016. Palaeoenvironmental characterization of a crocodilian nesting site from the Late Cretaceous of Brazil and the evolution of crocodyliform nesting strategies. Palaeogeography, Palaeoclimatology, Palaeoecology, 457:221232. doi:10.1016/j.palaeo.2016.06.020

Martin, J.A. 2013. Life traces of the Georgia coast: revealing the unseen lives of plants and animals. Bloomington, Indiana University Press, $670 \mathrm{p}$.

Martinelli, A.G.; Riff, D. \& Lopes, R.P. 2011. Discussion about the occurrence of the genus Aeolosaurus Powell 1987 (Dinosauria, Titanosauria) in the Upper Cretaceous of Brazil. Gaea - Journal of Geoscience, 7:34-40. doi:10.4013/gaea.2011.71.03

Mezzalira, S. 1974. Contribuição ao conhecimento da estratigrafia e paleontologia do arenito Bauru. São Paulo, Instituto Geográfico e Geológico, 163 p. (Boletim 51).

Mezzalira, S. \& De Simone, L.R.L. 1999. Duas novas espécies de Castalia (Mollusca, Bivalvia, Unionoida) no Cretáceo do Grupo Bauru, São Paulo, Brasil. Revista Geociências - UNG, 4:58-60.

Miall, A.D. 1996. The geology of fluvial deposits: sedimentary facies, basin analysis, and petroleum geology. Berlin, Springer-Verlag, 582 p. doi: 10.1007/978-3-662-03237-4

Miller, J.M.; Niraula, B.B.; Reategui-Zirena, E.G. \& Stewart, P.M. 2014. Life history and physical observations of primary burrowing crayfish (Decapoda: Cambaridae) Cambarus (Lacunicambarus) diogenes and Cambarus (Tubericambarus) polychromatus. Journal of Crustacean Biology, 34:15-24. doi:10.1163/1937240X-00002199

Mineiro, A.D.S.; Santucci, R.M.; Da Rocha, D.M.S; De Andadre, M.B; Nava, W.R. 2017. Invertebrate ichnofossils and rhizoliths associated with rhizomorphs from the Marília Formation (Echaporã Member), Bauru Group, Upper Cretaceous, Brazil. Journal of South American Earth Science, 80:529-540.

Nascimento, D.L.; Batezelli, A.; \& Ladeira, F.S.B. 2017a. First record of lobed trace fossils in Brazil's Upper Cretaceous paleosols: rhizoliths or evidence of insects and their social behavior? Journal of South American Earth Sciences, 79:364 376. doi:10.1016/j.jsames.2017.08.016

Nascimento, D.L.; Ladeira, F.S.B. \& Batezelli, A. 2017 b. Pedodiagenetic characterization of cretaceous paleosols in southwest Minas Gerais, Brazil. Revista Brasileira de Ciência do Solo, 41:e0160065. doi:10.1590/18069657rbcs20160065

Nyström, P. 2002. Ecology. In: D.M. Holdich (ed.) Biology of freshwater crayfish, Blackwell Sciences, p. 192-235.

Pereira, C.T.; Batezelli, A. \& Ladeira, F.S.B. 2015. Paleoprecipitation changes based on paleosols profiles of the Marilia Formation (Upper Cretaceous) in the eastern portion of the Bauru Basin in Southeastern Brazil. Revista Geociencias - UNG, 34:238-257.

Retallack, G.J. 2001. Soils of the past - an introduction to paleopedology. London, Unwin Hyman, 404 p.

Santucci, R.M. \& Bertini, R.J. 2001. Distribuição paleogeográfica e biocronológica dos Titanossauros (Saurishia, Sauropoda) do Grupo Bauru, Cretáceo Superior do sudeste brasileiro. Brazilian Journal of Geology, 31:307-315.

Smith, J.J.; Hasiotis, S.T.; Woody, D.T. \& Kraus, M.J. 2008. Paleoclimatic implications of crayfish-mediated prismatic structures in paleosols of the Paleogene Willwood formation, Bighorn basin, Wyoming, U.S.A. Journal of Sedimentary Research, 78:323-334. doi:10.2110/jsr.2008.040 
Soil Survey Staff. 1999. Soil Taxonomy a basic system of soil classification for making and interpreting soil surveys. $2^{\text {nd }} \mathrm{ed}$. Washington DC, Natural Resources Conservation Service, USDA, 886 p. (Agricultural Handbook 436).

Sonoki, I.K. \& Garda, G.M. 1988. Idades K-Ar de rochas alcalinas do Brasil meridional e Paraguai oriental: compilação e adaptação às novas constantes de decaimento. Boletim IG-USP, Série Cientifica, 19:63-85. doi:10.11606/issn.2316-8986.v19i0p63-85

Stoops, G.; Marcelino, V. \& Mees, F. 2010. Interpretation of micromorphological features of soils and regoliths. Amsterdam, Elsevier, $752 \mathrm{p}$.
Suguio, K. \& Barcelos, J.H. 1983. Calcretes of the Bauru Group (Cretaceous) Brazil: petrology and geological significance. Boletim IG-USP, Série Científica, 14:31-47. doi:10.11606/ issn.2316-8978.v14i0p31-47

Walls, J.G. 2009. Crawfishes of Louisiana. Baton Rouge, Louisiana State University Press, 256 p.

Received in December, 2016; accepted in November, 2017. 